\title{
Cherry laurel fruit extract counters dimethoate-induced reproductive impairment and testicular apoptosis
}

\author{
Elçin Bakır ${ }^{1}$, Serpil Sarıözkan², Burcu Ünlü Endirlik , Ayşe Baldemir Kılıç³, Arzu Hanım Yayª, \\ Fazile Cantürk Tan ${ }^{5}$, Ayşe Eken ${ }^{1}$, and Gaffari Türk ${ }^{6}$ \\ ${ }^{1}$ Erciyes University Faculty of Pharmacy, Department of Pharmaceutical Toxicology, Kayseri, Turkey, \\ ${ }^{2}$ Erciyes University Faculty of Veterinary Medicine, Department of Reproduction and Artificial Insemination, Kayseri, Turkey \\ ${ }^{3}$ Health Sciences University, Gülhane Faculty of Pharmacy, Department of Pharmaceutical Botany, Ankara, Turkey \\ ${ }^{4}$ Erciyes University Faculty of Medicine, Department of Histology and Embryology, Kayseri, Turkey \\ ${ }^{5}$ Erciyes University Faculty of Medicine, Department of Biophysics, Kayseri, Turkey \\ ${ }^{6}$ Firat University Faculty of Veterinary Medicine, Department of Reproduction and Artificial Insemination, Elazı̆̆, Turkey
}

[Received in March 2020; Similarity Check in March 2020; Accepted in October 2020]

Dimethoate is an organophosphorus pesticide used against agricultural insects, which causes oxidative stress and damage in many organs, including the reproductive ones. Cherry laurel (Laurocerasus officinalis Roem.) fruit is rich in vitamins and phenolic compounds with antioxidant effect. The aim of this study was to investigate how effective its extract would be against dimethoate-induced testis and sperm damage in rats. Sixty animals were divided in six groups of 10. Group 1 (control) received only $1 \mathrm{~mL}$ of saline $(0.9 \% \mathrm{NaCl})$. Group 2 received $7 \mathrm{mg} / \mathrm{kg}$ of dimethoate in $1 \mathrm{~mL}$ of saline. Group 3 received $4 \mathrm{mg} / \mathrm{kg}$ of extract in $1 \mathrm{~mL}$ of saline. Group 4 received the extract $30 \mathrm{~min}$ before dimethoate administration. Group 5 received vitamin C (positive control, $100 \mathrm{mg} / \mathrm{kg}$ in $1 \mathrm{~mL}$ of saline) $30 \mathrm{~min}$ before dimethoate administration. Group 6 received only dimethoate for the first four weeks and then a combination of dimethoate and extract for another four weeks. All doses were administered daily by oral gavage. After eight weeks of treatment, the rats were euthanised and their reproductive organs removed. We took their body and reproductive organ weights and evaluated testicular oxidative stress, semen characteristics, sperm DNA damage, testicular apoptosis, and histopathological changes. Dimethoate significantly decreased body and reproductive organ weights, sperm motility and concentration, testicular superoxide dismutase, and glutathione-peroxidase activities and significantly increased lipid peroxidation, abnormal sperm rate, sperm DNA damage, testicular apoptosis, and caused histopathological lesions. Cherry laurel extract significantly countered many dimethoate-induced adverse effects, both as pre- and post-treatment, including reproductive organ weight, semen parameters, oxidant-antioxidant balance, sperm DNA integrity, testicular apoptosis, and histological structure. Our findings clearly suggest that the beneficial effects of the extract are associated with countering oxidative stress, lipid peroxidation in particular.

KEY WORDS: Laurocerasus officinalis Roem.; organophosphorus pesticide; oxidative stress; sperm DNA damage; testis

Dimethoate is a widely used organophosphorus insecticide, toxic to vertebrates when taken by ingestion, inhalation, and dermal absorption $(1,2)$. It may cause reproductive toxicity, including low sperm count, sperm motility, blood testosterone, testis weight, and fertility and may lead to abnormal sperm development (3-5). It causes cellular injury and oxidative stress by overgeneration of reactive radicals and stimulation of lipid peroxidation (LPO) (6). It has also been reported to cause DNA damage and cytotoxicity (7-9).

Current in vitro and in vivo research seeks to effectively address oxidative stress-related health issues by tapping into our natural resources known to traditional medicine. One such resource is the cherry laurel (Laurocerasus

Corresponding author: Professor Gaffari Türk, Frrat University, Faculty of Veterinary Medicine, Department of Reproduction and Artificial Insemination, Elazig, Turkey, E-mail: gturk@firat.edu.tr officinalis Roem.), an evergreen plant that grows in humid and shady places in the area around the Black Sea. In Turkey it is known as taflan or karayemiş (10) and bears black or dark purple fruit resembling grape. It has long been known to Turkish traditional medicine for its diuretic and beneficial effects against gastric ulcer, digestive system disorders, bronchitis, and eczema (11). Research findings (12-14) confirm that it is rich in vitamin $\mathrm{C}$ and phenolic compounds, known for their antioxidant effects, but research of its protective effects is still scarce and, to the best of our knowledge, limited to neuroprotective and hepatoprotective effects $(14,15)$.

The aim of our study was therefore to address this gap by studying the effects of cherry laurel extract (CLE) against male reproductive toxicity of dimethoate through a number of parameters, including testicular oxidative stress, semen characteristics, sperm DNA integrity, apoptosis and testicular histology in rats. 


\section{MATERIALS AND METHODS}

\section{Chemical agents}

Dimethoate (Korumagor 40 EC, $40 \%$ emulsion) was purchased from Koruma Agriculture Co. (Kocaeli, Turkey). Other reagents and materials were purchased from SigmaAldrich Chemical Co. (St. Louis, MO, USA), unless otherwise specified.

\section{Plant material and preparation of fruit extract}

Cherry laurel fruits were collected from Akçaabat in the Turkish province of Trabzon. A voucher specimen (AEF 26257) has been deposited in the Herbarium of the Ankara University Faculty of Pharmacy, Turkey. We first washed the fruits with distilled water and separated the seed and the pulp. Only pulp was used to prepare CLE by drying it at $40{ }^{\circ} \mathrm{C}$ for five days. Twenty grams of dried fruits were macerated with $200 \mathrm{~mL}$ of methanol $(\mathrm{MeOH})$ at room temperature with constant magnetic stirring for $8 \mathrm{~h}$, and filtered on Whatman No. 1 filter paper. This procedure was repeated twice with $200 \mathrm{~mL}$ of $\mathrm{MeOH}$. The collected filtrates were dried under vacuum using a rotary evaporator at $40{ }^{\circ} \mathrm{C}$. They were then frozen and lyophilised to obtain the extract. Before experiments, the lyophilisate was dissolved in saline $(0.9 \% \mathrm{NaCl})$.

\section{Animals and experimental design}

For the experiment we used 60 male Wistar rats weighing approximately 200-250 g. The animals were kept in the Experimental and Clinical Research Centre of Erciyes University (Kayseri, Turkey) under standard laboratory conditions (12:12 h light and dark cycle, $22-24{ }^{\circ} \mathrm{C}$ temperature, and 55-60\% humidity), and had free access to commercial pellet diet (Optima Food Company, Bolu, Turkey) and water. The experimental procedures were approved by the Ethics Committee for Animal Research at Erciyes University and were carried out in compliance with international standards and national animal welfare legislation.

The animals were randomly divided into six groups of 10 to receive $4 \mathrm{mg} / \mathrm{kg}$ bw of CLE and $/$ or $7 \mathrm{mg} / \mathrm{kg}$ bw of dimethoate or $100 \mathrm{mg} / \mathrm{kg}$ bw of vitamin $\mathrm{C}$ by oral gavage every day for eight weeks. The tested dimethoate dose was calculated from the percentage of the active ingredient in the commercial preparation, and the doses of all three substances were based on earlier studies $(1,15)$. All were freshly dissolved in $1 \mathrm{~mL}$ of saline before use in the experiments. We opted for the eight-week treatment to cover the complete spermatogenic cycle in rats, which spans between 49 and 52 days (16).

Group 1 (control) received only $1 \mathrm{~mL}$ of saline. Group 2 received dimethoate alone. Group 3 received CLE alone. Group 4 received CLE $30 \mathrm{~min}$ before dimethoate administration. Group 5 received vitamin C 30 min before dimethoate administration (positive control), and group 6 received dimethoate alone for the first four weeks, and then a combination of dimethoate and CLE for the other four weeks.

\section{Specimen collection}

At the end of treatment, the rats were euthanised with an anaesthetic cocktail containing $8 \mathrm{mg} / \mathrm{kg}$ bw xylazine (Rompun $^{\circledR} 2 \%$, Bayer, Istanbul, Turkey) and $75 \mathrm{mg} / \mathrm{kg} \mathrm{bw}$ ketamine (Ketasol ${ }^{\circledR} 10 \%$, Interhas, Ankara, Turkey). Their whole body and absolute reproductive organ weights (testes, epididymides, seminal vesicle, and ventral prostate) were recorded in grams immediately and used to calculate relative organ weights (organ weight x 100 / whole body weight). One testis of each animal was fixed in Bouin's solution (a mixture of $15 \mathrm{~mL}$ picric acid $+5 \mathrm{~mL}$ formaldehyde $+1 \mathrm{~mL}$ glacial acetic acid) for $16 \mathrm{~h}$ for histopathological analysis. The other testis was stored at $-20{ }^{\circ} \mathrm{C}$ for oxidative stress analysis.

To determine sperm concentration, the right cauda epididymis was cut at the junction with the corpus epididymis, thoroughly dissected into small pieces with a scalpel and scissors into a Petri dish containing $1 \mathrm{~mL}$ saline, and the mixture was poured into an Eppendorf tube and left to incubate at room temperature for $4 \mathrm{~h}$ in order for all spermatozoa to pass into fluid. The left cauda epididymis was used to determine sperm motility and abnormality in a 5-10 $\mu \mathrm{L}$ suspension of spermatozoa (17).

\section{Analysis of oxidative stress parameters}

Frozen testicular tissues were put into 9-fold phosphate buffered saline (PBS), dissected into small pieces and homogenised in cold saline. We measured the levels of malondialdehyde (MDA) as an indicator of LPO and the activities of superoxide dismutase (SOD), glutathioneperoxidase (GPx), and catalase (CAT) as described earlier by Eken et al. (15) using an ultraviolet-visible spectrophotometer (Shimadzu, Tokyo, Japan) at the following absorbances: $532 \mathrm{~nm}$ for MDA, $505 \mathrm{~nm}$ for SOD, $340 \mathrm{~nm}$ for GPx, and $240 \mathrm{~nm}$ for CAT. MDA levels were expressed in $\mathrm{nmol} / \mathrm{mg}$ protein, and antioxidant enzyme activities in $\mathrm{U} / \mathrm{mg}$ protein.

\section{Analysis of semen parameters}

Semen analyses followed the methods described by Türk et al. (17). Sperm concentration in the right cauda epididymis was determined by a haemocytometer. Motility percentage in the left epididymal spermatozoa diluted with Tris buffer solution was visually determined at $400 \mathrm{x}$ magnification with the help of light microscope (Nikon Instruments Inc., Melville, NY, USA) with heated stage at $37{ }^{\circ} \mathrm{C}$. Abnormal spermatozoa were identified under the same microscope with 400x magnification on slides containing a mixture of eosin-nigrosin stain and sperm samples. Abnormalities included head (banana-shaped, 
broken-, flat-, double-, and curved-headed sperm) and tail defects (curved-, broken-, short-, and double-tailed sperm). A total of 200 spermatozoa were examined per slide, and the findings expressed as the percentage of abnormal spermatozoa. Total abnormality was also calculated as head + tail.

\section{Evaluation of sperm DNA damage}

We relied on the method described by Sarı̈zkan et al. (18). Briefly, diluted sperm samples were centrifuged (CN 090, Nüve, Ankara, Turkey) at $3000 \mathrm{x} g$ at $4^{\circ} \mathrm{C}$ for $10 \mathrm{~min}$ and supernatant removed. The remaining spermatozoa were washed with PBS without $\mathrm{Ca}^{2+}$ and $\mathrm{Mg}^{2+}$ to yield a concentration of $1 \times 10^{5}$ spermatozoa per mL. For DNA damage analysis we used the alkaline comet (single-cell gel electrophoresis) assay. Each microscope slide was precoated with a layer of $1 \%$ normal melting point (NMP) agarose in PBS and thoroughly dried at room temperature. Next, we mixed $100 \mu \mathrm{L}$ of $0.7 \%$ low melting point (LMP) agarose with $10 \mu \mathrm{L}$ of cell suspension at $37^{\circ} \mathrm{C}$ and dropped on top of the first slide layer. The slides were allowed to solidify in a moist box at $4{ }^{\circ} \mathrm{C}$ for $5 \mathrm{~min}$. Cover slips were removed and the slides immersed in a freshly prepared cold lysis buffer containing $2.5 \mathrm{~mol} / \mathrm{L} \mathrm{NaCl}, 100 \mathrm{mmol} / \mathrm{L} \mathrm{Na}_{2}-$ EDTA, $10 \mathrm{mmol} / \mathrm{L}$ Tris, $1 \%$ Triton X-100, $10 \%$ dimethyl sulphoxide (DMSO), and $40 \mathrm{mmol} / \mathrm{L}$ dithiothereitol $(\mathrm{pH}$ 10) at $4{ }^{\circ} \mathrm{C}$ for $1 \mathrm{~h}$. The slides were incubated in the lysis buffer with $100 \mu \mathrm{g} / \mathrm{mL}$ proteinase $\mathrm{K}$ at $37^{\circ} \mathrm{C}$ overnight. They were then removed from the lysis buffer, drained, and placed in a horizontal electrophoresis unit filled with fresh alkaline electrophoresis solution containing $300 \mathrm{mmol} / \mathrm{L}$ $\mathrm{NaOH}$ and $1 \mathrm{mmol} / \mathrm{L}$ EDTA (pH 13) for $20 \mathrm{~min}$ to allow the DNA to unwind. Electrophoresis $(12 \mathrm{~V}, 250 \mathrm{~mA})$ at $8{ }^{\circ} \mathrm{C}$ lasted $20 \mathrm{~min}$. The slides were then washed with a neutralising solution of $0.4 \mathrm{~mol} / \mathrm{L}$ Tris $(\mathrm{pH} 7.5)$ to remove alkali and detergents, stained with $50 \mu \mathrm{L}$ of $2 \mu \mathrm{L} / \mathrm{mL}$ ethidium bromide, and covered with a cover slip. All steps were performed under a dim light to prevent further DNA damage. For imaging and image analysis of 50 random nuclei per animal we used the Comet Assay Software Project for Windows (CASP-1.2.2, CaspLab, University of Wrocław, Wrocław, Poland)

\section{Histopathological examination}

Fixed testicular tissues were cut to $5 \mu \mathrm{m}$ thick slices and stained with Mayer's haematoxylin and eosin. Lesions like degeneration, congestion, and haemorrhage were examined semi-quantitatively in 20 seminiferous tubules, which were randomly selected in each section under a highresolution microscope (Olympus BX51, Tokyo, Japan) at 400x magnification. Two independent histologists analysed preparations in a blind fashion and photographed them with the same microscope.

\section{Assessment of testicular apoptosis}

Testicular apoptosis was determined using the terminal deoxynucleotide-transferase (TdT)-mediated dUTP nick end labelling (TUNEL) assay with in situ Cell Death Detection Kit (Roche Diagnostics GmbH, Mannheim, Germany) following the manufacturer's recommendations (19). Fixed testicular tissues were embedded in paraffin, sliced at $4 \mu \mathrm{m}$ thickness, deparaffinised in xylene, dehydrated with graded alcohol, washed in PBS, and treated with $0.05 \%$ proteinase $\mathrm{K}$ for $5 \mathrm{~min}$. Followed the treatment with $3 \%$ hydrogen peroxide for $5 \mathrm{~min}$ to inhibit endogenous peroxidase. After re-washing in PBS, slices were incubated with the TUNEL reaction mixture containing TdT enzyme and digoxigenin-11-dUTP in a humidified chamber at $37^{\circ} \mathrm{C}$ for $1 \mathrm{~h}$, and then with a stop/wash buffer for another $30 \mathrm{~min}$. For visualisation we used a diaminobenzidine substrate. Negative controls were treated with distilled water instead of TdT. For evaluation, 20 seminiferous tubules were randomly selected in each slide and TUNEL-positive apoptotic germ cells were counted on images obtained with the Olympus microscope (at 400x magnification) using the Image J program (Image J, Bethesda, MA, USA).

\section{Statistical analysis}

For statistical analysis we used the SPSS for Windows v. 22.0 (IBM Corp., Armonk, NY, USA). The inter-group comparisons were made with the non-parametric KruskalWallis and non-parametric Mann-Whitney $U$ tests. The results are expressed as means \pm standard error of mean (SEM). The level of statistical significance was set at $\mathrm{P}<0.05$.

\section{RESULTS}

\section{Body and reproductive organ weights}

CLE treatment alone significantly increased only seminal vesicle weight compared to control $(\mathrm{P}<0.001)$. Dimethoate, in turn, significantly decreased whole body, and organ weights $(\mathrm{P}<0.001)$. CLE pre- and post-treatment or vitamin $\mathrm{C}$ significantly countered these effects of dimethoate in the organs, but not in respect to the whole body weight (Tables 1 and 2).

\section{Oxidative stress parameters}

MDA levels and the activities of SOD, GPx, and CAT are presented in Table 3. Dimethoate significantly increased MDA levels $(\mathrm{P}<0.001)$ and significantly lowered SOD $(\mathrm{P}<0.01)$ and GPx $(\mathrm{P}<0.05)$ activities in comparison to control. These effects were significantly countered by preand post-treatment with CLE or vitamin $\mathrm{C}(\mathrm{P}<0.001$ for MDA, $\mathrm{P}<0.01$ for $\mathrm{SOD}$, and $\mathrm{P}<0.05$ for $\mathrm{GPx})$. CAT activities did not change significantly between the groups. 
Table 1 Effects of different treatments on whole body and absolute reproductive organ weights in rats

\begin{tabular}{|c|c|c|c|c|c|c|}
\hline \multirow[b]{2}{*}{ Groups } & \multirow[b]{2}{*}{$\begin{array}{c}\text { Body weight } \\
\text { (g) }\end{array}$} & \multicolumn{5}{|c|}{ Absolute reproductive organ weights (g) } \\
\hline & & $\begin{array}{c}\text { Testis } \\
\text { (Right+left/2) }\end{array}$ & $\begin{array}{c}\text { Whole } \\
\text { epididymis } \\
\text { (Right+left/2) }\end{array}$ & $\begin{array}{l}\text { Right cauda } \\
\text { epididymis }\end{array}$ & $\begin{array}{c}\text { Seminal } \\
\text { vesicle }\end{array}$ & $\begin{array}{l}\text { Ventral } \\
\text { prostate }\end{array}$ \\
\hline Control & $310.30 \pm 6.19^{\mathrm{a}}$ & $1.339 \pm 0.003^{\mathrm{a}}$ & $0.516 \pm 0.035^{\mathrm{a}}$ & $0.202 \pm 0.001^{\mathrm{a}}$ & $1.137 \pm 0.039^{\mathrm{a}}$ & $0.544 \pm 0.019^{\mathrm{a}}$ \\
\hline Dimethoate & $233.75 \pm 7.64^{b}$ & $0.878 \pm 0.012^{\mathrm{d}}$ & $0.260 \pm 0.010^{\mathrm{d}}$ & $0.111 \pm 0.007^{\mathrm{d}}$ & $0.761 \pm 0.007^{\mathrm{d}}$ & $0.298 \pm 0.003^{\mathrm{d}}$ \\
\hline CLE & $308.00 \pm 9.22^{\mathrm{a}}$ & $1.394 \pm 0.021^{\mathrm{a}}$ & $0.521 \pm 0.002^{\mathrm{a}}$ & $0.210 \pm 0.001^{\mathrm{a}}$ & $1.245 \pm 0.002^{\mathrm{b}}$ & $0.562 \pm 0.025^{\mathrm{a}}$ \\
\hline $\begin{array}{l}\mathrm{CLE}_{\text {pre }}^{+}+ \\
\text {dimethoate }\end{array}$ & $243.67 \pm 4.79^{\mathrm{b}}$ & $1.151 \pm 0.027^{\mathrm{b}}$ & $0.416 \pm 0.008^{\mathrm{b}}$ & $0.157 \pm 0.001^{\mathrm{b}}$ & $1.090 \pm 0.025^{\mathrm{a}}$ & $0.402 \pm 0.002^{\mathrm{bc}}$ \\
\hline $\begin{array}{l}\text { Vitamin } \mathrm{C}+ \\
\text { dimethoate }\end{array}$ & $253.70 \pm 2.51^{\mathrm{b}}$ & $1.209 \pm 0.003^{b}$ & $0.437 \pm 0.008^{\mathrm{b}}$ & $0.168 \pm 0.002^{\mathrm{b}}$ & $1.142 \pm 0.009^{\mathrm{a}}$ & $0.442 \pm 0.007^{\mathrm{b}}$ \\
\hline $\begin{array}{l}\text { Dimethoate + } \\
\text { CLE }_{\text {post }}\end{array}$ & $235.44 \pm 2.27^{\mathrm{b}}$ & $1.012 \pm 0.030^{\mathrm{c}}$ & $0.344 \pm 0.005^{\mathrm{c}}$ & $0.139 \pm 0.001^{\mathrm{c}}$ & $0.913 \pm 0.010^{\mathrm{c}}$ & $0.374 \pm 0.002^{\mathrm{c}}$ \\
\hline Median & 254.50 & 1.205 & 0.430 & 0.163 & 1.115 & 0.415 \\
\hline First quartile & 235.22 & 1.015 & 0.343 & 0.139 & 0.917 & 0.375 \\
\hline Third quartile & 303.00 & 1.340 & 0.520 & 0.203 & 1.240 & 0.540 \\
\hline $\begin{array}{l}\text { Interquartile } \\
\text { range }\end{array}$ & 67.89 & 0.33 & 0.18 & 0.06 & 0.29 & 0.16 \\
\hline
\end{tabular}

Data are expressed as mean \pm SEM. Different superscript letters $(a, b, c, d)$ in the same column denote significant differences between the groups $(\mathrm{P}<0.001)$. CLE - cherry laurel extract; $\mathrm{CLE}_{\text {pre }}$ - pre-treatment with CLE; $\mathrm{CLE}_{\text {post }}$ - post-treatment with CLE; SEM - standard error of the mean

Table 2 Effects of different treatments on relative reproductive organ weights in rats

\begin{tabular}{|c|c|c|c|c|c|}
\hline \multirow[b]{2}{*}{ Groups } & \multicolumn{5}{|c|}{ Relative reproductive organ weights* } \\
\hline & $\begin{array}{c}\text { Testis } \\
\text { (Right+left/2) }\end{array}$ & $\begin{array}{c}\text { Whole } \\
\text { epididymis } \\
\text { (Right+left/2) }\end{array}$ & $\begin{array}{l}\text { Right cauda } \\
\text { epididymis }\end{array}$ & Seminal vesicle & $\begin{array}{l}\text { Ventral } \\
\text { prostate }\end{array}$ \\
\hline Control & $0.433 \pm 0.009^{\mathrm{bc}}$ & $0.167 \pm 0.005^{\mathrm{ab}}$ & $0.065 \pm 0.001^{\mathrm{ab}}$ & $0.369 \pm 0.017^{b}$ & $0.176 \pm 0.007^{\mathrm{a}}$ \\
\hline Dimethoate & $0.379 \pm 0.014^{\mathrm{d}}$ & $0.113 \pm 0.007^{\mathrm{c}}$ & $0.047 \pm 0.003^{\mathrm{c}}$ & $0.328 \pm 0.012^{\mathrm{c}}$ & $0.129 \pm 0.005^{b}$ \\
\hline CLE & $0.456 \pm 0.013^{\mathrm{abc}}$ & $0.171 \pm 0.006^{\mathrm{a}}$ & $0.069 \pm 0.002^{\mathrm{a}}$ & $0.408 \pm 0.014^{\mathrm{ab}}$ & $0.184 \pm 0.010^{\mathrm{a}}$ \\
\hline $\begin{array}{l}\mathrm{CLE}_{\text {pre }}+ \\
\text { dimethoate }\end{array}$ & $0.474 \pm 0.041^{\mathrm{ab}}$ & $0.171 \pm 0.005^{\mathrm{a}}$ & $0.064 \pm 0.001^{\mathrm{ab}}$ & $0.448 \pm 0.014^{\mathrm{a}}$ & $0.166 \pm 0.003^{\mathrm{a}}$ \\
\hline $\begin{array}{l}\text { Vitamin C + } \\
\text { dimethoate }\end{array}$ & $0.477 \pm 0.016^{\mathrm{a}}$ & $0.172 \pm 0.004^{\mathrm{a}}$ & $0.066 \pm 0.001^{\mathrm{ab}}$ & $0.451 \pm 0.007^{\mathrm{a}}$ & $0.175 \pm 0.003^{\mathrm{a}}$ \\
\hline $\begin{array}{l}\text { Dimethoate + } \\
\text { CLE }_{\text {post }}\end{array}$ & $0.430 \pm 0.014^{\mathrm{c}}$ & $0.146 \pm 0.002^{\mathrm{b}}$ & $0.060 \pm 0.001^{\mathrm{b}}$ & $0.388 \pm 0.004^{\mathrm{b}}$ & $0.166 \pm 0.003^{\mathrm{a}}$ \\
\hline Median & 0.442 & 0.161 & 0.063 & 0.390 & 0.165 \\
\hline First quartile & 0.417 & 0.146 & 0.060 & 0.375 & 0.156 \\
\hline Third quartile & 0.469 & 0.174 & 0.068 & 0.443 & 0.183 \\
\hline $\begin{array}{l}\text { Interquartile } \\
\text { range }\end{array}$ & 0.060 & 0.028 & 0.008 & 0.063 & 0.025 \\
\hline
\end{tabular}

Data are expressed as mean \pm SEM. Different superscript letters $(a, b, c, d)$ in the same column denote significant differences between the groups $(\mathrm{P}<0.001)$. CLE - cherry laurel extract; $\mathrm{CLE}_{\text {pre }}$ - pre-treatment with CLE; $\mathrm{CLE}_{\text {post }}$ - post-treatment with CLE; SEM - standard error of the mean. * calculated by formula: absolute organ weight $(\mathrm{g})$ x $100 /$ whole body weight $(\mathrm{g})$

\section{Semen parameters}

CLE alone significantly increased sperm motility and concentration, while dimethoate significantly reduced sperm motility and concentration and significantly increased head, tail, and total abnormal sperm rate compared to control $(\mathrm{P}<0.001)$. Again, these effects were significantly countered by pre-and post-treatment with CLE or vitamin $\mathrm{C}(\mathrm{P}<0.001)$ (Table 4).

\section{Sperm DNA damage}

Dimethoate significantly increased sperm DNA damage versus control $(\mathrm{P}<0.001)$. This time only CLE pre-treatment significantly countered dimethoate-induced DNA damage ( $<<0.001$, Table 4). 


\section{Histopathology}

Figure 1 shows the microphotography of histopathological findings in the testes of each experimental group. The control group (Figure 1A) and the CLE alone group (Figure 1C) showed normal testis histology with regular seminiferous tubular morphology and germ cells with normal polarity at various levels of differentiation. The Sertoli and Leydig cells also showed normal structure and polarity. Dimethoate (Figure 1B) deteriorated the histological architecture of the testes, which included abnormal seminiferous tubules with damaged walls, capillary congestion, and haemorrhage in the testis. Compared to the dimethoate-treated group pre- and posttreatment with CLE (Figures 1D and F, respectively) and vitamin $\mathrm{C}$ (Figure 2E) resulted in fewer atrophic and degenerative changes in the tubular epithelium. In these experimental groups, the epithelium of the germ cell layer was well coordinated, and the interstitial tissue contained blood vessels with normal structure.

\section{Apoptosis}

Figure 2 and Table 4 show the presence of apoptotic cells in the testes of each group. Apoptotic germ cell count in the dimethoate-treated group was significantly higher than in all other groups $(\mathrm{P}<0.001)$. Pre- and post-treatment with CLE or vitamin $\mathrm{C}$ significantly reduced this count $(\mathrm{P}<0.001)$.
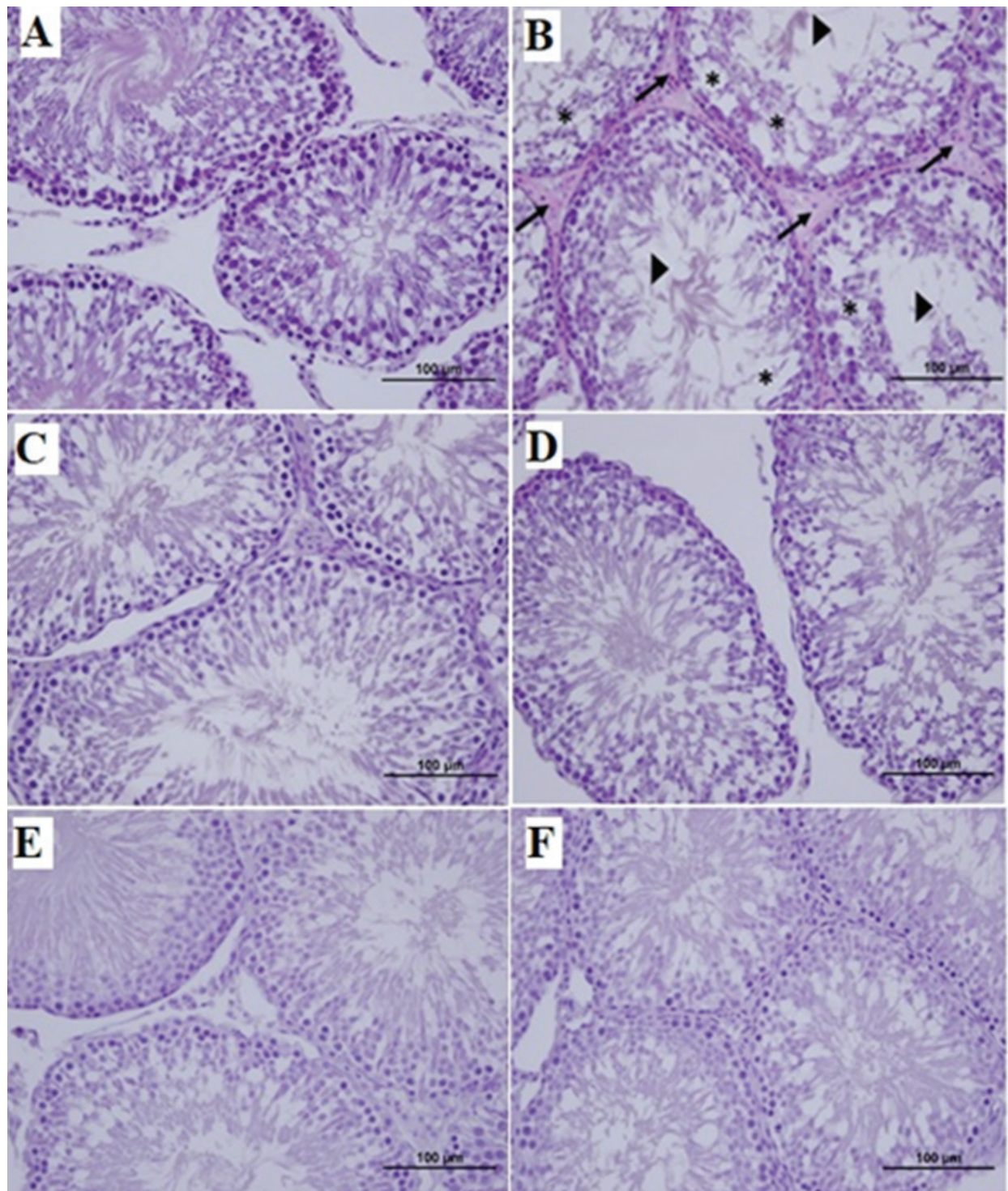

Figure 1 Light microscopy of testicular tissue in the experimental groups (H\&E, 20x). (A) normal seminiferous tubular morphology in control rats; (B) damaged testicular structure in dimethoate-treated rats (arrow head shows the lumens of seminiferous tubules containing fewer elongated spermatids; arrows show haemorrhage; asterisks show desquamation in germinal cells); (C) normal testis structure in rats treated with cherry laurel extract (CLE); (D) histology of the testicular tissue of rats pre-treated with CLE before receiving dimethoate; (E) normal seminiferous tubule morphology in the vitamin C-treated rats receiving dimethoate; (F) rare degenerated tubules and histopathological changes in rats receiving post-treatment with CLE 
Table 3 Effects of different treatments on malondialdehyde (MDA) levels and antioxidant enzyme activities in testicular tissue of rats

\begin{tabular}{lcccc} 
& \multicolumn{4}{c}{ Parameters } \\
\cline { 2 - 5 } Groups & $\begin{array}{c}\text { MDA } \\
\text { (nmol/mg protein) }\end{array}$ & $\begin{array}{c}\text { SOD } \\
\text { (U/mg protein) }\end{array}$ & $\begin{array}{c}\text { GPx } \\
\text { (U/mg protein) }\end{array}$ & $\begin{array}{c}\text { CAT } \\
\text { (U/mg protein) }\end{array}$ \\
\hline Control & $0.341 \pm 0.021^{\mathrm{x}}$ & $3.676 \pm 0.105^{\mathrm{a}}$ & $0.331 \pm 0.009^{\mathrm{A}}$ & $5.257 \pm 0.250$ \\
\hline Dimethoate & $0.486 \pm 0.021^{\mathrm{y}}$ & $3.174 \pm 0.090^{\mathrm{b}}$ & $0.265 \pm 0.012^{\mathrm{B}}$ & $4.291 \pm 0.244$ \\
\hline CLE & $0.386 \pm 0.017^{\mathrm{x}}$ & $3.635 \pm 0.078^{\mathrm{a}}$ & $0.335 \pm 0.017^{\mathrm{A}}$ & $4.068 \pm 0.282$ \\
\hline CLE ${ }_{\text {pre }}+$ dimethoate $_{\text {Vitamin C }+ \text { dimethoate }}$ & $0.377 \pm 0.015^{\mathrm{x}}$ & $3.603 \pm 0.066^{\mathrm{a}}$ & $0.326 \pm 0.014^{\mathrm{A}}$ & $4.681 \pm 0.310$ \\
\hline Dimethoate + CLE $_{\text {post }}$ & $0.362 \pm 0.012^{\mathrm{x}}$ & $3.662 \pm 0.079^{\mathrm{a}}$ & $0.327 \pm 0.014^{\mathrm{A}}$ & $4.828 \pm 0.257$ \\
\hline Median & $0.367 \pm 0.028^{\mathrm{x}}$ & $3.614 \pm 0.114^{\mathrm{a}}$ & $0.329 \pm 0.017^{\mathrm{A}}$ & $5.114 \pm 0.294$ \\
\hline First quartile & 0.380 & 3.650 & 0.320 & 4.700 \\
\hline Third quartile & 0.330 & 3.320 & 0.290 & 3.945 \\
\hline Interquartile range & 0.430 & 3.805 & 0.355 & 5.360 \\
\hline Daryyyy
\end{tabular}

Data are expressed as mean \pm SEM. Different superscript letters in the same column denote significant differences between the groups: ${ }^{\mathrm{A}, \mathrm{B}}-\mathrm{P}<0.05 ; \mathrm{a}, \mathrm{b}-\mathrm{P}<0.01{ }^{\mathrm{x}, \mathrm{y}}-\mathrm{P}<0.001$. CAT - catalase; CLE - cherry laurel extract; $\mathrm{CLE}_{\text {pre }}$ - pre-treatment with CLE; $\mathrm{CLE}_{\text {post }}-$ posttreatment with CLE; GPX - glutathione-peroxidase; SEM - standard error of the mean; SOD - superoxide dismutase

\section{DISCUSSION}

Our findings confirmed the adverse effects of subchronic dimethoate exposure on the reproductive system in male rats. In line with other reports (20-23), it significantly decreased body and reproductive organ weights. These losses are likely to be associated with lower food intake (22) and lower testosterone (23) and thyroid (21) secretion. Although we did not measure hormone levels to demonstrate this association, it is well-known that thyroid hormones $\left(\mathrm{T}_{3}\right.$ and $\mathrm{T}_{4}$ ) are necessary for the growth (21), while testosterone governs the development and function of male reproductive organs (24). Both are affected by oxidative stress evidenced in our study.

Our dimethoate-induced oxidative stress findings are also in line with previous reports, indicating overproduction of free radicals or reactive oxygen species (ROS) that react with membrane lipids, producing cell and tissue damages $(20,25,26)$. Dimethoate administration has been reported to stimulate oxidative stress in rats (20), as evidenced by increased LPO and decreased tissue activities of SOD, CAT and GPx (27). In our study, MDA levels significantly increased, while SOD and GPx activities significantly decreased after dimethoate administration. The same is true for semen parameter findings, which support earlier dimethoate reports (3-5). Jallouli et al. (5) reported a significant drop in sperm concentration, motility, viability, and antioxidant enzyme activities and a significant rise in abnormal-shaped spermatozoa and LPO level in dimethoatetreated mice. Ben Abdallah et al. (3) observed that dimethoate concentrations of 50,100, and $200 \mu \mathrm{mol} / \mathrm{L}$ caused significant oxidative injury in spermatozoa, accompanied with increased MDA levels, and significantly lower sperm motility, viability, and SOD, CAT, and GPX activities. Farag et al. (4) found that oral dimethoate doses of 15 and $28 \mathrm{mg} / \mathrm{kg}$ reduced sperm motility and production but did not change the ratio of abnormal-shaped spermatozoa in mice. Sperm DNA damage, and histopathological findings have already been reported for organophosphorus pesticides such as acephate (27), diehylthiophosphate (28), and cypermethrin (29). An earlier study (23) reported some histopathological lesions, such as oedema, haemorrhage, degenerated seminiferous tubules, atrophy, sloughing, degeneration and spermatogenic arrest in testes after dimethoate treatment. As the reason for the oxidant/ antioxidant imbalance in testes the authors of that study suggested overproduction of free radicals and ROS in response to dimethoate administration. Besides, deteriorations in semen parameters, sperm DNA and testicular histology are likely to be associated with dimethoate-induced increase in LPO.

Cherry laurel has strong radical (hydroxyl and superoxide) scavenging and antioxidant activities because it contains high levels of pectin, phenolic compounds, vitamins (A, C, D), and minerals (10-14). Since its antioxidant effect is similar to or higher than vitamin C (11), vitamin $\mathrm{C}$ was used as reference antioxidant in this study. Eken et al. (15) have reported that CLE significantly counters dimethoate effects in rats by lowering increased liver MDA levels, pathological lesions, and DNA damage and by significantly increasing low SOD, GPx, and CAT activities in the liver. We too observed that CLE showed a great potential against dimethoate-induced oxidative stress and its consequences, and our findings support the results of an in vivo CLE study by Y1lmaz (30), which demonstrated improvements in total sperm count, vitality and motility and mitigation of oxidative stress and histopathological lesions against the side effects of a chemotherapy drug methotrexate.

To date, no other study investigated CLE's potential against dimethoate-induced reproductive damage, and our study provides significant new evidence on this issue. Pre- 


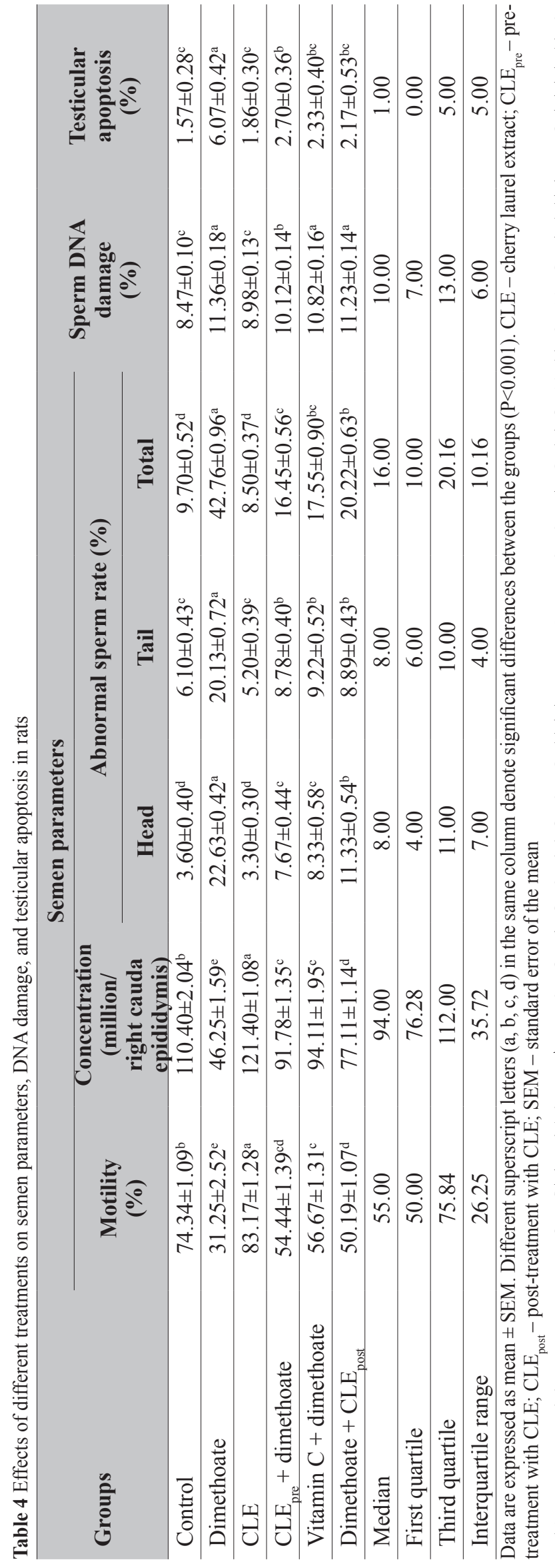

and post-treatment with CLE resulted in significant restoration of nearly all organ, semen, and oxidative stress parameters to normal values. The exception is that only pre-treatment was effective against sperm DNA damage caused by dimethoate.

The improvement in oxidant/antioxidant balance, semen parameters, sperm DNA integrity, testicular apoptosis, and histology observed in our study are possibly associated with the strong radical scavenging and antioxidant activity of CLE. Sperm plasma membrane is rich in polyunsaturated fatty acids, which are particularly sensitive to free radical attacks (25). The lowering of LPO in sperm plasma membrane by antioxidative action of CLE seems to entail improvements in semen parameters, lowering of DNA damage and apoptosis, and restoration of normal testicular histology. Besides, improved histological structure after CLE treatment seems to explain increase in testicular weight. The increase in epididymis weight may be associated with increased sperm count, and the increase in accessory sex gland weights with increased fluid content.

\section{CONCLUSION}

Our findings in the rat model provide evidence that the protective effects of CLE against dimethoate-induced reproductive damage in rats are similar to those of vitamin $\mathrm{C}$ and suggest that consumption of CLE by humans and animals exposed to organophosphorus pesticides like dimethoate may improve protection of male reproduction. Before we jump into any conclusion about human risk assessment, however, we should consider the metabolic differences between rat and human metabolism. In addition, this study tested the effects of a single pesticide and CLE concentration, and further in vivo research should involve a broader dose range.

\section{Acknowledgements}

This study was financially supported by the Research Fund of the Erciyes University Scientific Research Project Unit (Grant No: TCD-2013-4127). The manuscript was presented at the $9^{\text {th }}$ Congress of the Turkish Society of Toxicology with the participation of the Hellenic Society of Toxicology in İzmir, Turkey.

\section{Conflict of interest}

None to declare.

\section{REFERENCES}

1. Sayim F. Dimethoate-induced biochemical and histopathological changes in the liver of rats. Exp Toxicol Pathol 2007;59:237-43. doi: 10.1016/j.etp.2007.05.008

2. Verma R, Mohanty B. Early-life exposure to dimethoateinduced reproductive toxicity: evaluation of effects on 

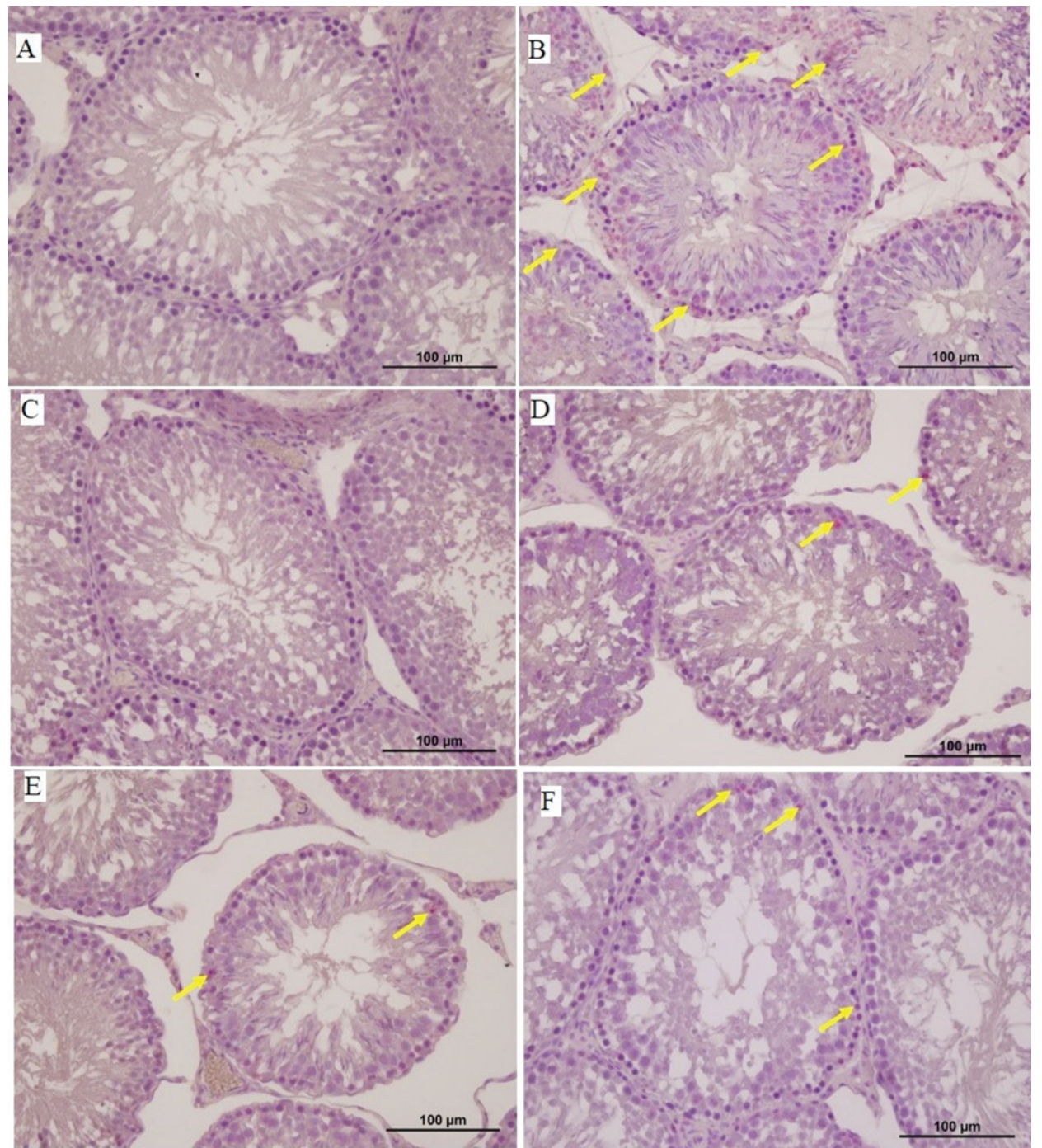

Figure 2 Apoptotic germ cells (arrows) in testicular tissues (H\&E, 400x). (A) the control group; (B) in the dimethoate alone group, many TUNEL-positive apoptotic cells were found; (C) cherry laurel extract (CLE) alone group; (D) CLE pre-treatment decreased the number of TUNEL-positive apoptotic cells in rats receiving dimethoate; (E) vitamin C-treated group receiving dimethoate; (F) CLE post-treatment group receiving dimethoate

pituitary-testicular axis of mice. Toxicol Sci 2009;112:450 8. doi: 10.1093/toxsci/kfp204

3. Ben Abdallah F, Fetoui H, Zribi N, Fakfakh F, Ammar-Keskes L. Antioxidant supplementations in vitro improve rat sperm parameters and enhance antioxidant enzyme activities against dimethoate-induced sperm damages. Andrologia 2012;44:272-9. doi: 10.1111/j.1439-0272.2011.01177.x

4. Farag AT, El-Aswad AF, Shaaban NA. Assessment of reproductive toxicity of orally administered technical dimethoate in male mice. Reprod Toxicol 2007;23:232-8. doi: 10.1016/j.reprotox.2006.12.003

5. Jallouli M, El Bini DI, Dhouib H, Gharbi N, El Fazaa S. Effects of dimethoate in male mice reproductive parameters. Regul Toxicol Pharmacol 2015;73:853-8. doi: 10.1016/j. yrtph.2015.10.010

6. Spodniewska A, Zasadowski A. Content of glutathione and vitamin $\mathrm{C}$ in the liver of rats exposed to dimethoate and pyrantel tartrate. Acta Vet Brno 2008;77:355-62. doi: 10.2754/avb200877030355
7. Ahmad W, Shaikh S, Nazam N, Lone MI. Protective effects of quercetin against dimethoate-induced cytotoxicity and genotoxicity in Allium sativum test. Int Schol Res Notices 2014;Article ID 632672. doi: 10.1155/2014/632672

8. Sharma Y, Bashir S, Irshad M, Gupta D, Dogra TD. Dimethoate-induced effects on antioxidant status of liver and brain of rats following subchronic exposure. Toxicology 2005;215:173-81. doi: 10.1016/j.tox.2005.06.029

9. Ündeğer Ü, Başaran N. Effects of pesticides on human peripheral lymphocytes in vitro: induction of DNA damage. Arch Toxicol 2005;79:169-76. doi: 10.1007/s00204-0040616-6

10. Halilova H, Ercisli S. Several physico-chemical characteristic of cherry laurel (Laurocerasus officinalis Roem.) fruits. Biotechnol Biotechnol Equip 2010;24:1970-3. doi: 10.2478/ V10133-010-0059-6

11. Kolaylı S, Küçük M, Duran C, Candan F, Dinçer B. Chemical and antioxidant properties of Laurocerasus officinalis Roem. (cherry laurel) fruit grown in the Black Sea region. J Agric Food Chem 2003;57:7489-94. doi: 10.1021/jf0344486 
12. Colak A, Özen A, Dincer B, Güner S, Ayaz FA. Diphenolases from two cultivars of cherry laurel (Laurocerasus officinalis Roem.) fruits at an early stage of maturation. Food Chem 2005;90:801-7. doi: 10.1016/j.foodchem.2004.06.004

13. Yaylac1-Karahalil F, Şahin H. Phenolic composition and antioxidant capacity of cherry laurel (Laurocerasus officinalis Roem.) sampled from Trabzon region, Turkey. Afr J Biotechnol 2011;10:16293-9.

14. Erdogan-Orhan I, Küpeli-Akkol E. Estimation of neuroprotective effects of Laurocerasus officinalis Roem. (cherry laurel) by in vitro methods. Food Res Int 2011;44:818 22. doi: 10.1016/j.foodres.2011.01.037

15. Eken A, Ünlü Endirlik B, Bakır E, Baldemir A, Yay AH, Cantürk F. Effect of Laurocerasus officinalis Roem. (cherry laurel) fruit on dimethoate induced hepatotoxicity in rats. Kafkas Univ Vet Fak Derg 2017;23:779-87. doi: 10.9775/ kvfd.2017.17748

16. Bennett JP, Vickery BH. Rats and mice. In: Hafez ESE, editor. Reproduction and breeding techniques for laboratory animals. Philadelphia, USA: Lea and Febiger; 1970. p. 299-315.

17. Türk G, Ateşşahin A, Sönmez M, Yüce A, Ceribaşı AO. Lycopene protects against cyclosporine A-induced testicular toxicity in rats. Theriogenology 2007;67:778-85. doi: 10.1016/j.theriogenology.2006.10.013

18. Sarı̈zkan S, Türk G, Güvenç M, Yüce A, Özdamar S, Cantürk F, Yay AH. Effects of cinnamon (C. zeylanicum) bark oil against taxanes-induced damages in sperm quality, testicular and epididymal oxidant/antioxidant balance, testicular apoptosis and sperm DNA integrity. Nutr Cancer 2016;68:481-94. doi: 10.1080/01635581.2016.1152384

19. Roche. In situ Cell Death Detection Kit [displayed 26 October 2020]. Available at: https://www.sigmaaldrich.com/content/ dam/sigma-aldrich/docs/Roche/Bulletin/1/11684795910bul. pdf.)

20. Abu El-Saad AM, Elgerbed MSA. Dimethoate-induced hepatotoxicity in rats and the protective roles of vitamin $\mathrm{E}$ and N-acetylcysteine. Egypt J Exp Biol (Zool) 2010;6:219-30.

21. Mahjoubi-Samet A, Hamadi F, Soussia L, Fadhel G, Zeghal N. Dimethoate effects on thyroid functions in suckling rats. Ann Endocrinol (Paris) 2005;66:96-104. doi: 10.1016/s00034266(05)81705-6

22. Ngoula F, Watcho P, Kenfack A, Manga JN, Defang HF, Pierre K, Joseph T. Effect of dimethoate (an organophosphate insecticide) on the reproductive system and fertility of adult male rat. Am J Pharmacol Toxicol 2014;9:75-83. doi: 10.3844/ajptsp.2014.75.83

23. Afifi NA, Ramadan A, El-Aziz MI, Saki EE. Influence of dimethoate on testicular and epididymal organs, testosterone plasma level and their tissue residues in rats. Dtsch Tierarztl Wochenschr 1991;98:419-23. PMID: 1764985

24. Klinefelter GR, Hess RA. Toxicity of the excurrent ducts and accessory organs in the male. In: Korach KS, editor. Reproductive and developmental toxicology. New York: Marcel Dekker; 1998. p. 553-91.

25. Türk G. [Physiologic and pathologic effects of reactive oxygen species on spermatozoon functions, in Turkish]. Türkiye Klinikleri J Reprod Artif Insemin-Special Topics 2015;1:26-34

26. Sivapiriya V, Sakthisekaran J, Venkatraman S. Effects of dimethoate (O,O-dimethyl S-methyl carbomoyl methyl phosphorodithioate) and ethanol in antioxidant status of liver and kidney of experimental mice. Pestic Biochem Phys 2006;85:115-21. doi: 10.1016/j.pestbp.2005.12.001

27. Thamali Dhanushka MA, Peiris LDC. Cytotoxic and genotoxic effects of acephate on human sperm. J Toxicol 2017; Article ID 3874817. doi: 10.1155/2017/3874817

28. Sanchez-Pena LC, Reyes BE, Lopez-Carrillo L, Recio R, Moran-Martinez J, Cebrian ME, Quintanilla-Vega B. Organophosphorous pesticide exposure alters sperm chromatin structure in Mexican agricultural workers. Toxicol Appl Pharmacol 2004;196:108-13. doi: 10.1016/j. taap.2003.11.023

29. Zalata A, Elhanbly S, Abdalla H, Serria MS, Aziz A, ElDakrooy SA, Mostafa T. In vitro study of cypermethrin on human spermatozoa and the possible protective role of vitamins C and E. Andrologia 2014;46:1141-7. doi: 10.1111/ and.12206

30. Y1lmaz G. Siçanlarda methotrexate kaynaklı testis hasarına karş1 Laurocerasus officinalis Roem. (Karayemiş)'in antiapoptotik ve antioksidan etkileri. [Antiapoptotic and antioxidant effects of Laurocerasus officinalis Roem. (cherry laurel) against methotrexate-induced testicular damage in rats, in Turkish]. [MSc thesis]. Trabzon: Institute of Health Sciences; 2014. 


\section{Ekstrakt lovorvišnje ublažava štetno djelovanje dimetoata na reproduktivnu funkciju i apoptozu stanica u testisu} štakora

Dimetoat je organofosforni insekticid koji uzrokuje oksidacijski stres i oštećuje mnoge organe, uključujući reproduktivne. Plod lovorvišnje (Laurocerasus officinalis Roem.) bogat je vitaminima i fenolnim spojevima s antioksidacijskim djelovanjem. Cilj je ovoga istraživanja bio utvrditi djelotvornost njegova ekstrakta protiv oštećenja testisa i spermija u mužjaka štakora izloženih dimetoatu. Njih 60 podijeljeno je nasumce u šest skupina od deset životinja. Prva je (kontrolna) skupina primala samo $1 \mathrm{~mL}$ fiziološke otopine $(0,9 \% \mathrm{NaCl})$, druga skupina $7 \mathrm{mg} / \mathrm{kg}$ dimetoata u $1 \mathrm{~mL}$ fiziološke otopine, treća skupina $4 \mathrm{mg} / \mathrm{kg}$ ekstrakta lovorvišnje u $1 \mathrm{~mL}$ fiziološke otopine, četvrta skupina ekstrakt 30 minuta prije primjene dimetoata, peta skupina vitamin C (pozitivna kontrola, $100 \mathrm{mg} / \mathrm{kg} \mathrm{u} 1 \mathrm{~mL}$ fiziološke otopine) 30 min prije primjene dimetoata, a šesta skupina primala je dimetoat u prva četiri tjedna, potom kombinaciju dimetoata i ekstrakta lovorvišnje u sljedeća četiri tjedna. Sve navedene doze davane su svaki dan gavažom. Nakon osam tjedana primjene, štakori su eutanazirani, a njihovi reproduktivni organi odstranjeni. Izmjerena im je ukupna tjelesna masa i masa reproduktivnih organa te ocijenjen oksidacijski stres u testisima, značajke sjemena, oštećenja DNA spermija, apoptoza u testisima i histopatološke promjene. Dimetoat je značajno smanjio masu tijela i organa, gibljivost i koncentraciju spermija te aktivnost superoksid dismutaze i glutation-peroksidaze, a značajno povisio lipidnu peroksidaciju, postotak abnormalnih spermija, oštećenje DNA spermija, apoptozu u testisima te uzrokovao histopatološke promjene tkiva. Ekstrakt lovorvišnje značajno je ublažio te štetne učinke, bilo da je davan prije ili nakon dimetoata. Naši rezultati jasno upućuju na blagotvorno djelovanje toga ekstrakta, koje je povezano sa zaštitom od oksidacijskoga stresa, napose od lipidne peroksidacije.

KLJUČNE RIJEČI: Laurocerasus officinalis Roem.; oksidacijski stres; organofosforni pesticidi; oštećenje DNA spermija; testis 